\title{
Conjunctive Management Through Collective Action
}

\author{
Cameron Holley, Darren Sinclair, Elena Lopez-Gunn, \\ and Edella Schlager
}

\begin{abstract}
This chapter focuses on the interaction between conjunctive management and collective action. Collective action has several characteristics that provide a natural 'fit' with conjunctive management. These include building trust and ownership to enhance water user's acceptance of the need for better and more integrated management and resolving conflict and facilitating trade-offs between and across water users. But what are the opportunities and challenges for conjunctive management through collective action? And what types of settings encourage broadbased collective action by water users and governments? These questions are addressed through a comparative analysis of specific instances of groundwater governance in Australia, Spain, and the western United States of America. For each case, the diverse policy and institutional settings are explained, and consideration given to the motivators for, and successes of, conjunctive management and collective action. The chapter draws comparisons across the cases to suggest lessons on incentives for conjunctive management, as well as exploring its challenges, before identifying future directions for more effective integrated water management.
\end{abstract}

This research was partially funded by an ARC Discovery Early Career Researcher Award (DE140101216) and an ARC Linkage Grant (LP130100967).

C. Holley $(\bowtie)$

University of New South Wales, Kensington, Australia

e-mail: c.holley@unsw.edu.au

D. Sinclair

The Australian National University, Canberra, ACT, Australia

E. Lopez-Gunn

ICATALIST, Madrid, Spain

IE Business School, Madrid, Spain

E. Schlager

The University of Arizona, Tucson, AZ, USA

(C) The Author(s) 2016

A.J. Jakeman et al. (eds.), Integrated Groundwater Management,

DOI 10.1007/978-3-319-23576-9_9 


\subsection{Introduction}

Diverse policy and institutional settings provide different types of incentives for engaging in adaptive integrated cyclical management of surface water and groundwater (aka conjunctive management). This chapter's interest lies in the interaction between conjunctive management and collective action. In particular, it focuses on the opportunities for, and challenges of, conjunctive management and collective action as a combined strategy for managing variable water supply and incorporating options for environmental watering.

While there is no settled, precise definition of conjunctive management, it can be broadly conceived as involving the integration of water management decisionmaking and action to maximise the benefits arising from the innate characteristics of surface water and groundwater water use (e.g. surface water resources are more visible and measurable, but more variable and typically more difficult to store) (Evans et al. 2012; SKM 2011). Conjunctive management can take various forms, for example, engineered (e.g. aquifer storage and recovery; see Chaps. 16 and 17), non-engineered (e.g. integrated water planning; see Chap. 8 and Ross 2012a), bottom up (e.g. at the farm level of sourcing water from both a well and from an irrigation delivery canal, with some accompanying monitoring and evaluation to develop local management objectives) and top down (e.g. a more strategic approach where surface water and groundwater inputs are centrally managed/planned for) (Evans et al. 2012, pp. 4, 6).

Crucially, conjunctive management is not limited to the coordinated or joint use of surface water and groundwater, but rather the coordinated use of a portfolio of resources, of which groundwater is particularly important for three key reasons. First, groundwater has an in-built advantage during drought since it offers an important buffer to climate variability due to its relative stability (and thus lowers the risk). Second, it is a relatively inexpensive resource when compared to alternative climate independent sources such as desalinated or recycled water, with their comparatively high energy costs. Third, it affords enhanced agency or control to water users such as farmers through devolved decision-making (as compared to surface water systems).

The inherent appeal of conjunctive management lies in the unity (or connectedness) of the hydrological cycle. Recognising that the characteristics of water resources vary according to the relative and particular contributions of surface water and groundwater, this strengthens the case for examining opportunities for collective (and integrated or coordinated) management. Indeed, the use of connected groundwater and surface water systems can have significant implications for both water quantity and quality of each, respectively (Brodie et al. 2007). Abstraction from either can affect the quantity, quality and reliability/accessibility of abstraction from the other, as well as impacting on the water supply to conjunctive dependent ecosystems (e.g. low flows in rivers and certain wetlands) (SKM 2011, p. 4).

Alarmingly, the 'disjointed' use of groundwater can lead to undesirable effects (Lopez-Gunn et al. 2011) ranging from a rise in piezometric levels, increasing the risk of flooding and/or subsidence, problems of drainage and salinisation or marine intrusion, the lowering of piezometric levels and higher pumping costs, and if connected 
to surface water flows, to a reduction in flows which can negatively affect wetlands, springs, groundwater dependent ecosystems and river base flows. Conversely, conjunctive management in a conscious and coordinated way (Andreu et al. 2010) can ameliorate or even prevent many of these problems. This is where collective action comes into its own by engaging water users as key conjunctive management participants. Overseen by well-designed water rights systems, this can lead to better and more integrated management outcomes. In this respect, collective action can take various forms - between different tiers of government, between government and water users, and between groups of water users themselves (Holley et al. 2011).

Collective action has several characteristics that provide a natural 'fit' with conjunctive management. These include, in particular: the planning and day-today management of water; contributing local knowledge to assist in the development of a common understanding of water systems; building trust and ownership to enhance water user's acceptance of the need for better and more integrated management (Baldwin et al. 2012); and resolving conflict and facilitating trade-offs between and across water users (SKM 2011; Brodie et al. 2007, p. 78).

Given these potential attractions, what types of settings encourage broad-based collective action by water users and governments to deliver conjunctive management? And what are the opportunities and challenges for conjunctive management through collective action? These questions are addressed via a comparative analysis of specific instances of groundwater governance in Australia, Spain and the western United States of America, three leaders in water reform and conjunctive management approaches. Each national case study outlines the diverse policy and institutional settings, and considers the motivators for, and successes of, conjunctive management and collective action. Reflecting the diverse forms of conjunctive management, the national cases explore various conjunctive management approaches, including integrated basin and catchment planning in Australia, United States and Spain, as well as augmentation plans/agreements and large-scale water infrastructure projects involving storage and desalination in the United States and Spain. The chapter concludes by drawing comparisons across the cases to suggest lessons on incentives for conjunctive management, as well as exploring its challenges, before identifying future directions for more effective integrated water management.

\subsection{Conjunctive Management: Experiences from Australia, Spain and the United States of America}

\subsubsection{Australia}

By the latter stages of the twentieth century, significant weaknesses in Australia's water regulation began to emerge. In particular, state governments were granting many new water licences to irrigators and others, with generous extraction allocations attached (Bricknell 2010; Gray 2010). Under these arrangements surface water and groundwater resources were generally managed separately (Ross 2012a). Subsequent fears of over-allocation and severe water shortages soon 
emerged. Broadly speaking, this crisis motivated state and federal governments to come together and collaboratively address accelerating degradation of water sources (Godden and Foerster 2011).

The result was a new national water management regime. Commencing in 1994, and later taking shape under the National Water Initiative (NWI) in 2004, Australia came to recognise connectivity between surface water and groundwater resources and the need to manage connected systems as a single resource (Commonwealth of Australia and the Governments of New South Wales, Victoria, Queensland, South Australia, the Australian Capital Territory and the Northern Territory 2004, para 23 (x)). This included acknowledging hydrological connectivity considerations relating to trading of water rights (which have been separated from land), management of environmental water, and most importantly for present purposes, the use of collaborative planning for delivering integrated management of surface water and groundwater (IANWI, paras 58(i), 79(i) (c), Schedule E, 5(ii); NWC 2008, p. 2).

Collaborative planning is now central to the pursuit of conjunctive use management in Australia and is the primary instrument for achieving collective action between governments and water users. As such, NWI principles include consultation with stakeholders, adaptive management of surface water and groundwater systems and consideration of the level of connectivity between surface water and groundwater systems (IANWI, paras 23(x), 25(iv), Schedule E, 5(ii), 6(i)). The concept of connectivity has also been recognised in the recent Murray-Darling Basin Plan (Basin Plan, Cth, 2012, cl10.19).

Individual state jurisdictions have considerable flexibility in how they implement these principles (Tan et al. 2012). In practice, however, water plans commonly contain: rules for water allocation; rules for transferring water entitlements or allocations; environmental outcomes; limits on extraction in certain places or at certain times; and monitoring and reporting requirements (Gray 2012). Conjunctive management is taken into account across these various elements, including in identifying the environmental values and assets, setting the plan's objectives, and choosing the management tools to implement the plan (NWC 2011a, p. 99). Consequently, the number of water plans that recognise surface water and groundwater connectivity is growing (NWC 2011a, p. 99).

Despite this success, conjunctive water management has been piecemeal and slow. For instance, few groundwater dependent ecosystems have well-established environmental water requirements or effective monitoring programs (Lamontagne et al. 2012). Further, while available modelling and data is improving, the historical under-resourcing of data collection and analysis, and limited metering and enforcement of extraction, particularly of groundwater, have inhibited progress (Holley and Sinclair 2013a; Holley and Sinclair 2012; Baldwin et al. 2012, p. 75). Indeed, as the National Water Commission explains, "Quantifying surface and groundwater connectivity and aligning their management is unfinished business in most jurisdictions... While all jurisdictions have developed policies for managing connected surface water and groundwater systems, the implementation of effective conjunctive management remains limited and the understanding of connectivity in individual systems is still inadequate in many areas" (NWC 2011a, pp. 10, 100). 
Why has conjunctive management remained 'unfinished' in Australia? And what are the opportunities and barriers to conjunctive management and collective action? These issues remain unresolved, not least because answers are likely to vary between states and catchments. A comprehensive review of these experiences is beyond a chapter of this size, so we instead draw some general insights on the challenges and opportunities of conjunctive management through a collaborative planning case study (for further on this study and its methods, see Holley and Sinclair 2013b, pp. 37-38).

New South Wales (NSW) was selected because of its diverse range of surface water and groundwater resources, and it is at the forefront of integrated water management (Ross 2012a). Water sharing plans (WSPs) are employed to address competing demands through rules for water use and trading and are developed under the Water Management Act 2000 (NSW). The Act gives effect to the NWI goal of sustainable and integrated water management, including the role of the community in working with government to resolve water management issues (Water Management Act 2000, s 3). Most NSW WSPs take the form of 'Minister's Plans' rather than as a result of a formal collaborative committee process (Water Management Act 2000, ss 15, 50; Holley and Sinclair 2013b; Millar 2005). In making the WSP, the Minister has the power to set up advisory or other committees for the purposes of the Water Management Act and, as shown below, this was used in lieu of a more formal collaborative committee route (Water Management Act 2000, ss 387, 388).

The first of NSW's over 60 WSPs commenced in the early 2000s and were prepared using a local committee approach with stakeholder consultation (NWC 2011 b, p. 10). This study focuses on the development of one of these earlier plans in a small upper catchment in the Namoi Valley, chosen because its surface water channels exhibit a number of points of high connectivity with the local groundwater system (SWS 2012, pp. vii, 103; Parsons et al. 2008; Kelly et al. 2007). The particular 'zone' is subject to the Water Sharing Plan for the Upper and Lower Namoi Groundwater Sources 2003 (covering 13 zones in total).

The catchment has a single river flowing through it, but this is usually dry as it sits on top of a porous alluvial groundwater system, which is rapidly recharged from the surface river water. In short, it is a highly connected system. The catchment is populated by a comparatively small number of farmers (with 33 licence holders, but only around 15 active water users), with small holdings (around 40 ha). Other major stakeholders engaged in water management were a government department for water (the New South Wales Office of Water (NOW) (now known as DPI Water)), the Namoi Catchment Management Authority (CMA) (now known as North West Local Land Services), a number of local councils and other property holders who did not actively use the groundwater.

Notwithstanding that much of the groundwater resource is highly connected to the Namoi River, the development of our groundwater WSP case was separated from a surface WSP in the Namoi (NWC 2011b, p. 130). Both WSP's began as single resource drafts prior to the NWI being agreed at the national level. While the NWI was finalised before the groundwater WSP was completed, the ultimate plan provide little information on the potential connectivity between surface water and groundwater (NWC 2011b, p. 131). 
The groundwater planning process began with the release of a socioeconomic study into the region, followed by some initial consultation meetings in each zone of the Namoi Valley (approximately $42,000 \mathrm{~km}^{2}$ in total, containing 100,000 people) along with a series of related technical studies. With the Water Management Act in place in 2000, a groundwater management committee was established to cover the Namoi region. The committee included representatives from all the major stakeholder groups highlighted above, and other relevant department and fishing bodies, and had responsibility for developing the draft WSP, which it released in 2002 (Millar 2005, p. 9). Up to this point, there was little direct consultation with stakeholders outside of the committee process (Holley and Sinclair 2013b).

The draft WSP was scheduled to begin operation in 2003 and was to be made under s50 of the Water Management Act as a Minister's Plan. Following some controversy over the operation and amendment of s50 to exclude certain requirements relating to public consultation, and an unsuccessful legal challenge the WSP was put on hold while a review of the draft plan was undertaken (Millar 2005). This engaged representatives from peak irrigation bodies, and addressed in particular the issue of uniform and proportional reductions versus allocation based (at least partially) on 'history of use'. In order to execute this policy the implementation of six groundwater plans was deferred so the department could establish accurate information on the historical rates of extraction for all licensees (Gardner et al. 2009, p. 320). Subsequently, a new revised WSP was completed in 2005, and was scheduled to commence in 2006. In the interim, another far more comprehensive round of consultation was undertaken with the assistance of the existing stakeholder committee and the Namoi CMA. In terms of impact, the CMA consultation process amended approximately a third of the clauses in the draft WSP. The Minister approved the WSP, with the weighting of allocations favouring active users over inactive users (see also New South Wales Government NSWG 2011). The WSP came into force on 1 November 2006, and terminates on 30 June 2017.

While there were some disagreements over the mechanics of the above consultation process, there were also key differences and disputes over its nature and outcomes. These differing perceptions are fundamental to understanding the failure of conjunctive management in this instance, and reveal ongoing unresolved disputes between the different actors. Although there was, and remains, some tension regarding entitlement reductions, of fundamental relevance were disputes between government and non-government stakeholders. Holley and Sinclair's (2013b, pp. 44-50) research on the experiences of this case study zone reveal four key areas of contention.

First the zone's irrigators and NOW disagree as to the nature and content of the consultation process that led to final WSP. In particular, the irrigators reported that they were deceived by NOW as to a proposal for integrated water management involving variable groundwater allocations that reflected highly connected surface water and groundwater system and resulting rapid aquifer recharge by a stream in their zone. The underlying rationale of the irrigators' case was that the rapid aquifer recharge in their zone could have been better harnessed to optimise water use during wet and dry periods, including exploring storage options and more flexible annual allocations. In essence, this would have entailed management rules that were 
more responsive to changing aquifer levels via a seasonal allocation of the catchment as a whole, as opposed to a fixed sustainable yield as is common under WSPs. For the irrigators, a more integrated planning process would have allowed them to make trade-offs between flexibility and the security of water entitlements in order to make better use of existing water supplies. This would have required frequent monitoring of the catchment aquifer and river flows, such that water use protected environmental flows. The rationale for this approach was that farmers would be able to engage in a cooperative form of local governance (with external oversight), in particular, adapting their management strategies in response to changes in river flows and aquifer levels.

The irrigators believe they were given a firm undertaking by NOW (and its predecessors) to seriously consider their proposal to respond to their catchments biophysical conditions and put in place flexible integrated seasonally variable targets: "they said they would look at it". In contrast, the government claims no such undertaking was given, nor did they receive any written proposals to that effect from the irrigators. These different interpretations emerged from a decision-making and consultation process that saw significant mistrust and disconnection between government and the irrigators. One irrigator was of the view that "the [proposal] fell over because farmers were not respected by NOW, and were not trusted to manage the groundwater". Whilst not agreeing with the irrigators' interpretation of events, even NOW respondents acknowledged that shortcomings in the consultation process for the irrigators (discussed further below) had contributed to these fundamental divisions.

Despite the support of local farmers, in the end, the suggested management approach was not adopted. The opportunities for more flexible exchanges between different uses was instead overlooked in favour of groundwater only WSP, where water users were given annual allocations that were tied to groundwater levels in the catchment.

A second area of contention was the negotiation process in the lead up to the WSP zone allocations. On all accounts, the process was time consuming but had successfully involved many peak groups and, in the later stages, many farmers. Even so, smaller irrigators and local farmers believe they ultimately had little say (let alone an opportunity to contribute to a consensus agreement) in a decisionmaking process that was dominated by large, downstream cotton irrigators and governments. NOW respondents also acknowledged shortcomings in the consultation process for the case study's irrigators, particularly in earlier stages:

\footnotetext{
There wasn't a lot of consultation at local level with irrigators ... I don't know how up to date they were on what was happening and the decisions being made above them. They were out of the loop really. Government and peak irrigators were the main groups really throughout the entire process
}

Third, even when the CMA engaged local irrigators in the latter stages of the process, there were reportedly significant weaknesses in facilitating meaningful negotiation. Although NOW and the CMA had provided significant technical information on water conditions and hydrological modelling, and that some connectivity estimates were incorporated into their underlying hydrological models 
(NWC 2011b), sufficient information was not always available to properly account for groundwater-surface water interactions (Lamontagne et al. 2012). At the time, stakeholders raised questions about the information used to assist with complex decision-making. As one government respondent put it: "I guess by its nature, complicated was necessary". According to respondents, the lack of sufficient government assistance effectively precluded many local irrigators from fully understanding and inputting into issues of connectivity and the implications for conjunctive management. As one government respondent explained:

\footnotetext{
Another issue was the complexity of the model - because of this complexity, some irrigators never really got it ... You know you will always have people at one end of the room who are switched on, and then you will have others who enjoy farming but not following up issues and reading things. In hindsight some of the presentations could have been simpler.
}

Fourth, and finally, and perhaps the biggest weakness, was that despite models underpinning the WSPs, the resulting plan lacked sufficient provisions for integrated management of connectivity (NWC 2011b, p. 14). Arguably, this has constrained adaptation opportunities and the incorporation of conjunctive management approaches. Indeed, even if one has faith in the fact that hydrological models underpinning the plan continue to reflect aspects of connectivity modelling itself, sufficient information is reportedly not always available to account for groundwater-surface water exchanges in detail. Indeed, respondents pointed out that relevant government agencies have failed to generate and share relevant hydrological data, including an absence of information on their groundwater aquifer status and trends (Holley and Sinclair 2011). As one catchment management respondent noted, "they [NOW] are supposed to do Aquifer Status reports on a quarterly basis, but we are lucky if we get a report every three years".

There was a similar lack of sustained data sharing/dialogue between state and regional institutions and the water users themselves, namely, the farmers. Following the implementation of the WSP, it was claimed by catchment management respondents that at first "the Department came along with good reports, but then this stopped and people quickly lost interest". Consequently, the farmer consultation groups became dormant. Despite the availability of some data online, farmers said they lacked the time and skills to find, access, use and then interpret relevant information: "they tell us it's in the public domain but they can't find the time to show us how to get to it and look at it" (Holley and Sinclair 2011). In the absence of such data, effective water management (including ongoing monitoring and scrutiny of the WSP itself) is difficult, with minimal information reported on the achievement of environmental or cultural outcomes, or progress towards these (NWC 2011b, p. 131).

Despite recent recognition of these issues there is still a long way to go until successful conjunctive management of groundwater can be realised in catchments such as this case study. Certainty, there are limits to generalising from a single case (e.g. see the distinct history of developments relating to conjunctive management of seawater intrusion, Petheram et al. 2008). However many of these findings appear consistent with recent national evaluations (NWC 2011a). It is also important to 
remember that the case study was an early example of planning. The new Basin Plan (Basin Plan 2012, Cth, cl10.19), ongoing review of WSPs in NSW (NSW Office of Water 2013; NRC 2013) and new integrated and macro plans that aggregate water sources into broader management units (O'Rourke and Bailey 2010) provide evidence and opportunities for necessary refinement to management of groundwater surface water connections (NWC 2011b, p. 11). For example, the recent Water Sharing Plan for the Peel Valley Regulated, Unregulated, Alluvium and Fractured Rock Water Sources 2010 represents a substantial advancement in NSW's approach to integrated management of surface water and groundwater, including different sets of rules to manage water resources with varying degrees of connectivity (e.g. shallow alluvial groundwater below a river channel can be managed by the same rules as surface water, whereas groundwater remote from the river channel is managed as a separate resource) (Ross 2012b). Positive signs for conjunctive management are also evident in the growth of managed aquifer recharge (whose uptake in Australia has been patchy among different states, Dillon et al. 2009, 2010) and national efforts to improving resource condition data (Water Regulations 2008, Cth, Part 7). However, the full potential and impact of these developments is still some years away, and it is clear that despite over a decade of national objectives the implementation of conjunctive water systems through planning is lagging.

\subsubsection{Spain}

Conjunctive water use is widespread in Spain, both in the interior (e.g. Madrid's water supply as the capital region is now underpinned by conjunctive use) (Flores Montoya 1998), and along the Mediterranean coast, all the way from the internal basins of Catalonia, down to the Jucar, the Segura and finally the Almeria basin. Two features are peculiar to conjunctive use. The first is the role of water user groups in the management of this conjunctive use. The second is the fact that conjunctive use along the Mediterranean coastline (where there are high value crops and economically important tourism) is seeking to enlarge the portfolio of resources to reduce risk beyond surface water and groundwater, and is now incorporating desalinated, recycled and even recharged water (López-Gunn et al. 2012). This means that management is complex both from the perspective of resource management, and also in terms of coordination between a number of actors. The leading ones are, however, the water user groups as ground managers, and the respective river basin authority as the regulator.

Groundwater in Spain is a strategic resource in a number of basins and states (Sahuquillo 2009). It is not a particularly noticeable resource in the Northern part, whereas in parts of central Spain, like La Mancha or Almeria, it is the key water resource for the regional economy. In the case of Catalonia, conjunctive water use is part of day-to-day management, with a highly complex system of resource management. People and economic activity has concentrated along the coastline, where intensive groundwater use has led to problems with both marine intrusion 
and water quality, for example in the deltas of the Llobregat, Besos, Ter, Muga and Francoli rivers (Planas 2010). Intensive use affects the cities in the region, and has led to a complex management including built seawater barriers to prevent marine intrusion and projects for aquifer recharge. The experiences on aquifer recharge in the Besós and Llobregat rivers (Barcelona) are complemented with the pilot experience with the Río Belcaire (Castellón), which together represent $50 \mathrm{Mcm}^{3}$ / year for the whole of Spain (Andreu et al. 2010).

However in terms of resource use, what is noticeable is that rather than conjunctive use it is a case of 'alternate' use, i.e. surplus surface water is used to recharge local aquifers for times when there is low surface water availability. The case of the Cubeta de San Andreu is interesting because of the confluence between complex resource use and a complex institutional framework that is needed for the conjunctive use to run smoothly. The current plan for water resources is based on the joint use of surface, groundwater, re-used water and desalination and water transfers. This is a change from individual use to collective management, led under the umbrella groundwater user group for Catalonia, the specific one of the Cubeta de San Andreu, the public water supply company ATLL, and the regional water administration through specific agreements.

The agreement signed between users and the regional water agency provides a framework for a project of joint interest, e.g. aquifer recharge, covering technical, legal and economic aspects. It includes aspects related to aquifer recharge, inventory of water rights and the closing of some wells, the installation of water meters and monitoring, technical advice, a chemical monitoring network and preparatory work for the EU Water Framework Directive (WFD). Thus the goals or objectives are both public and private. The main obstacles have been to reach enough level of association and common vision, and closer links between administration agencies (like agriculture and water admin), as well as giving political voice and representation to users in the decision-making bodies.

The case of Andalusia, in particular, the region of Almeria, bears some similarities to the case of Arizona, except with one major difference: it is for use in the largest greenhouse area in the world, the so-called 'plasticulture'.

In the late 1990 s to early 2000 , with a lack of groundwater management in the southern Mediterranean coastal belt, authorities looked to divert water from the Ebro river in the north to help compensate for rapidly depleting aquifers (Llamas et al. 2007). Water agencies tend to build projects far in advance of their justifiable need on pure economic terms (Howe 2002). It is politically rational for decision makers to prefer users to continue pumping than to take the (unpopular) decision to cut allocations and instead opt for politically more popular water transfers. There are very few systems of explicit conjunctive management. Once the National Hydrological Plan of 2001 was derailed, Plan B centred on the construction of a series of desalination plants along the coast, including Almeria. However, Spanish farmers - like Arizona farmers - also balked at paying for expensive desalinated water in bulk to substitute groundwater abstractions. However, in an ironic twist, farmers do use desalinated water - which they consider 'fresh' to blend it with highly salinised groundwater with high conductivities, which is an optimal solution 
in terms of lowering the risk of no water, while ensuring optimal conductivity for high value tomato crops destined for export in Northern Europe. Farmers prefer cheaper groundwater to desalinated water, despite the fact that desalinated water prices are subsidised and do not reflect the true costs (which are borne by the taxpayer).

The case of Jaen in the Upper Guadalquivir basin offers a completely different narrative. Here, the discussion on conjunctive use is happening at the basin level, partly because groundwater farmers upstream started intensive use of relatively small aquifers, using water that technically was already 'allocated' to farmers downstream. However farmers downstream were more 'inefficient' in terms of Euros per drop (productivity) and also in terms of resource use $\left(\mathrm{m}^{3}\right.$ per crop) which has created a negotiation space. Intensive groundwater use upstream has meant the rapid development of a region that was economically depressed, and where there are now political pressures to keep these captured resources. Since in Spain, contrary to the United States, there is no prior appropriation doctrine, it is the river basin authority through basin planning that becomes the object of negotiation for groundwater user communities upstream and surface water communities downstream. In one case, defending what are rather tenuous 'use' rights as compared to full 'de jure' water rights. Yet it is an example where once this intensive groundwater use has happened (it is fait accompli), the most likely scenario is to upscale collective action to basin level in order to achieve the best possible 'conjunctive' use of both surface water and groundwater resources (Rica et al. 2014).

Looking at the Jucar case we see an interesting evolution in terms of conjunctive use, from really early experiences dating to the early twentieth century, all the way to current decisions being posed on conjunctive use on the river basin plan being prepared in 2013. In this context the case of the river Mijares and irrigation in the Plain of Castellon is a good example of conjunctive management, defined as consisting both of the joint (or alternate) use (resource organization) and joint use by users (social organization). An agreement was signed in 1970 to use water from the Mijares River (Convenio de bases para la ordenación de las aguas del río Mijares, 1970, OM-MOP-73), based on making use of the storage capacity of the aquifer (estimated at $600 \mathrm{Mcm}^{3}$ ) five times larger than the reservoirs of Sichar and Maria Cristina, which had filtrations. Thus during dry periods use is made of groundwater which is recharged during the wetter years by making use of surplus flows from surface irrigation in the acequias or canals (Andreu et al. 2010).

The Jucar case offers some similarities to the case of Colorado, in the United States, and to the case of the Guadalquivir, with a classic conflict between intensive use of groundwater upstream and impacts on surface water users downstream. In the first instance, like in other cases discussed in this chapter, there was a negotiation between farmers in the Eastern Mancha aquifer in Albacete with the Jucar river basin authority. However, during times of high water scarcity - in the midst of a drought - like in the case of Colorado, the temporary solution was an augmentation plan, to address the problem of low flows in the Jucar river, which eventually impacted downstream into the Acequia Real del Jucar (a traditional surface water irrigation area highly dependent on these flows). The Water Act of 1999 introduced 
Table 9.1 Results Ofertas Públicas de Adquisición de Derechos (OPAD)

\begin{tabular}{l|l|l}
\hline & 2007 & 2008 \\
\hline Applications submitted: & 119 & 234 \\
\hline Volume in rights $\left(\mathrm{Mcm}^{3}\right)$ & 56.8 & 109.6 \\
\hline Volume waived without economic compensation $\left(\mathrm{Mcm}^{3}\right)$ & 22.9 & 12.5 \\
\hline Volume offered $\left(\mathrm{Mcm}^{3}\right)$ & 27.3 & 50.6 \\
\hline Budget used $($ million $€)$ & 5.5 & 12.7 \\
\hline Reserved volume $\left(\mathrm{Mcm}^{3}\right)$ & 6.6 & 46.5 \\
\hline
\end{tabular}

Source: Ferrer and Garijo 2013

an important change by partially introducing market instruments under the figures of contract for the assignment of rights (Article 67 TRLA) and a centre for the exchange of water rights (Article 71 TRLA) (Ferrer and Garijo 2013). The first case has not been used frequently between users because it is fairly restrictive on the type of water right. Most groundwater rights are private and these are barred from participating in water rights exchanges. In the 2005-2008 drought, however, the river basin authority negotiated with Eastern Mancha farmers for an area of 28,000 ha on the basis of a series of criteria centred on impact on river flows and price offered. Exchange purchases went from $20 \%$ to $5 \%$ of the irrigation, securing $148 \mathrm{Mcm}^{3}$ bought with (temporary) reductions to prevent the drying up of the river bed as had occurred in the previous drought from 1994 to 1996.

It is important to stress that it is likely that this negotiation and agreement was facilitated to a large degree due to the existence of a well-organised and cohesive groundwater user group that acted as interlocutor with the river basin authority. Thus after the emergency meeting due to drought from the Spanish Council of Ministers in 2004, Centres for the Exchange of rights (art. 71) were set up in the Guadiana, Júcar y Segura which authorised these basins to undertake Public Offers for the (temporary) Acquisition of Rights (Ofertas Públicas de Adquisición de Derechos (OPAD)) (Table 9.1).

During the 2006-2008 drought other types of conjunctive management were undertaken in the Jucar, including the use of non-conventional resources like drainage flows from the Ribera del Jucar of up to $60 \mathrm{Mcm}^{3} /$ year via pumping (costs paid by users); and water re-use (up to $94 \mathrm{Mcm}^{3} /$ year) where treated water from Valencia city was partially exchanged for surface water in the Vega del Turia thus freeing up Jucar resources. These were initiatives for conjunctive use using all available resources and using a modelling programme to explore the different options, including leading to a better comprehension by users of the range of alternatives (Andreu et al. 2010).

The Jucar case is one of the best studied and most complex in Spain and one which highlights a range of available models for conjunctive use as discussed by Garduño et al. (2010). Equally, Andreu (a Spanish expert on conjunctive use (Andreu et al. 1996; Andreu et al. 2010)), highlights the diversity of experiences in Spain on conjunctive use not discussed here for reasons of space, and the common denominator for their durability: success centred on collective action 
and adequate rules of game, which have to envisage different scenarios, give particular emphasis to drought conditions and define the economic regime. What is particularly relevant at a more macro scale from the perspective of joint use and collective action is to make more flexible the opportunities for exchanges between different uses as argued by Ferrer and Garijo (2013). At the catchment level scale, conjunctive use of water opens up an interesting constellation of mutual interests between surface water and groundwater, public water supply and irrigation and the most suitable use of best quality water. Transfer of rents between sectors from those that have a higher capacity to pay could also solve one of the most intractable problems in the basin.

In conclusion, conjunctive management in Spain is a reality in many cases and it has become particularly valuable as a solution to complex problems, where in general the complexity of the resource use has been matched by the emergence of parallel social institutions and collective entities to address conjunctive management.

\subsubsection{United States of America}

In the United States, the primary authority over the allocation of ground and surface water resides with states. Each state has its own water laws and water administration system making it difficult to generalise about water policy in the United States (Getches 2008). Although the states are the lead actors in deciding whether and how conjunctive management occurs, the federal government is often a participant because of its authority over different activities that impact water. Beginning in the early twentieth century, the federal government began a long-term program of financing and building large surface water storage and delivery projects (Reisner 1993). The projects are often sources of water for conjunctive management programs. Later, in the 1970s, environmental laws extended the reach of the federal government. In particular, the Endangered Species Act has impacted how states and their water users place water to productive uses (Aiken 1999).

Since it is impossible to adequately address the water experiences of each of the 50 states, this section focuses on the experiences of three western states, Arizona, Colorado, and Nebraska. These three states were selected because of their variation in water administration that in turn has affected their experiences with conjunctive water management. Arizona's water arrangements are highly centralised within the Arizona Department of Water Resources (ADWR), which administers groundwater and conjunctive water management programs. Local jurisdictions, such as irrigation districts, cities and counties deliver water to end users, but have limited discretion in governing water (Colby and Jacobs 2007). In contrast, Nebraska's water arrangements are highly fragmented. Local natural resources districts have the primary authority to manage groundwater, whereas the Nebraska Department of Natural Resources has the authority to manage surface water (Harnsbarger 1984). Until very recently, the state held minimal decision making authority over groundwater, thus making it difficult to coordinate groundwater and surface water uses. 
Finally, Colorado may be characterised as more of a polycentric system. Concurrent and overlapping powers to govern water are shared across the three branches of government - specialised water courts, the state water engineer, and the legislature - with water users organised in irrigation districts and companies, well associations, and municipal water utilities (Blomquist et al. 2004). No single branch of government or local or regional water organization dominates water governance.

While each state's water laws, administration, and experiences are different, each state turned to conjunctive water management to provide solutions to a series of conflicts confronting water users and the state governments. It is the nature of the conflicts, combined with the state's water laws and water geography that shaped conjunctive water management responses. For Arizona, conjunctive water management emerged from conflicts over how to develop and use its allocation of Colorado River water. Allotted over 2 million acre feet of water annually from the river, it required a multi-billion dollar project of canals and pumping stations to deliver a substantial portion of that water to the most populous areas of the state. One of a number of conditions that Arizona accepted in order for the US Bureau of Reclamation to build the $\$$ (US) 4.8 billion Central Arizona Project was to adopt a new state groundwater code that would regulate groundwater pumping and limit the mining of groundwater (Leshy and Belanger 1988). The 1980 Arizona Groundwater Management Act established the framework for conjunctive management. It created four active management areas (AMAs), later expanded to five when one of the original AMAs was split in two, extending from central Arizona south to the international border with Mexico. Within the active management areas, agricultural groundwater rights were quantified and capped and municipalities were subject to limits and over time reductions in the amounts of groundwater they could pump to serve their residents (Leshy and Belanger 1988). The portions of Arizona not covered by active management areas continued under the historic groundwater regulatory regime of reasonable use (Colby and Jacobs 2007).

By the early 1990s, the Central Arizona Project was complete and began delivering water, however, the state faced a serious crisis. The state intended to repay its portion of the cost of constructing the project by selling water. The primary water users, irrigators, balked at purchasing the water because it was substantially more expensive than pumping groundwater. Over the course of several years, negotiations among the Federal government, state, and municipal, agricultural, and rural interests resulted in revisions to the 1980 Groundwater Management Act, some of which encouraged the recharge of Central Arizona Project water underground to be withdrawn at a later date (Glennon 1995). Large water districts, municipal utilities, and the Arizona Water Banking Authority have developed a series of direct and indirect recharge projects storing several million acre feet of water over the past decade. For instance, from 1997 to 2012, the Arizona Water Banking Authority which recharges 'surplus' Central Arizona Project water has accumulated over 3 million acre feet of recharge credits (Arizona Water Banking Authority 2013).

Arizona has a highly focused and directed conjunctive water management program - long term underground storage of its allotment of Colorado River 
water. The millions of recharge credits are likely to become an important source of water for irrigators and municipal water providers in the next couple of decades because of anticipated water shortages in the Colorado River Basin due to extended drought and climate change impacts.

Colorado, like Arizona, also has active conjunctive management programs and projects in place in the most heavily populated river basins in the state. However, the conflicts that stimulated a conjunctive management response and the resulting practice of conjunctive management are distinct. The first century of European settlement and economic development, roughly between 1849 and 1949, was supported by the construction of surface water storage and distribution systems. Water development was based on and supported by the prior appropriation doctrine in which water is allocated on a first in time, first in right basis. During times of scarcity, those water users most senior in time receive their water allotments while those more junior in time bear the water shortages. The State Water Engineer administers water rights and develops information for water courts to guide the creation, modification, and transfer of water rights. Water courts are the venue in which water users bargain, negotiate, and contest over water rights (Blomquist et al. 2004).

Beginning in the 1950s, irrigators began installing high capacity wells. Within a decade, groundwater pumping began to noticeably affect river and stream flows. Under Colorado water law, groundwater that is hydrologically connected to surface waters is governed under the prior appropriation doctrine. In practice, this meant that groundwater rights were junior to surface water rights and under the prior appropriation doctrine wells should not be pumped until surface water rights were satisfied. Such a strict application of the prior appropriation doctrine would shut off access to a major source of water, one that is particularly important during times of drought, and limit the expansion of irrigated agriculture and municipal and industrial development. Conflict between Colorado surface water and groundwater users also spilled across state borders as water users in downstream states claimed that they were being denied their rights to water by groundwater pumping occurring upstream in Colorado. Efforts to incorporate groundwater into the state's prior appropriation system and to ensure that interstate water allocation agreements are adhered to largely rest on conjunctive management programs and projects (Blomquist et al. 2004).

In Colorado, conjunctive management protects and maintains surface water flows while allowing for groundwater pumping. The state legislature passed a series of laws that gave the state water engineer the authority to engage in rule making and that allowed for the development and use of augmentation plans. Augmentation plans, which must be approved by water courts (as must any rules and regulations developed by the State Water Engineer), allow well owners to augment stream flows to cover the effects of groundwater pumping. Augmentation plans may take a variety of forms. Well owners may lease surface project water and make it available to the Colorado state water engineer to release to the stream or river when needed. Or, they may purchase surface water rights and leave the associated water in the stream to cover the effects of groundwater pumping. Or, some irrigation companies 
and districts run surface water in irrigation ditches and ponds, allowing it to percolate into the ground and eventually return to the river to cover the effects of groundwater pumping (Blomquist et al. 2004). Wells not covered by court approved augmentation plans have been shut down (Cowan 2012).

Like Colorado, Nebraska's conjunctive water management efforts have been directed at protecting and maintaining river and stream flows. Surface water is governed by the prior appropriation doctrine and is administered by the Department of Natural Resources. Groundwater is governed by local natural resources districts that have the authority to regulate groundwater access and use. Each district is governed by an elected board, and elected members are typically irrigators who pump groundwater. Until recently, the state had no authority over groundwater and natural resource districts were not required to pay attention to the effects of groundwater pumping on surface water flows (Schlager and Blomquist 2008).

The efforts to coordinate groundwater and surface water use occurred because of crises in relation to surface water users. In the Platte River Basin the surface water users were endangered species and in the Republican River Basin the surface water users resided in the downstream state who claimed that Nebraska groundwater pumpers were in violation of an interstate water sharing agreement. The endangered species in the Platte River Basin limited new water development and threatened existing water uses that required permits from federal agencies (Aiken 1999). Most importantly for Nebraska, the state's largest water and electric utility held permits issued by the Federal Electric Regulatory Commission to operate hydroelectric dams that were soon to expire. Permit renewal would require aggressive actions to protect endangered species. The two upstream states in the basin faced similar threats to their water projects as well. The three states and the federal government, over the course of a decade, negotiated an agreement that provided additional flows to the river for endangered species recovery and to cover all water development that affected the river from 1997 onward (Schlager and Blomquist 2008; Freeman 2010; Kenny 2011). One of the sticking points in achieving an agreement was Nebraska actively regulating groundwater wells and pumping in the basin. The upstream states did not want to provide additional water to the river only to have it diverted by irrigators in Nebraska (Freeman 2010). At about the same time, the 1990s, the state and irrigators in the Republican River Basin were gearing up for a US Supreme Court suit brought by Kansas, the downstream state claiming that Nebraska's well owners were diverting water that belonged to Kansas irrigators, causing Nebraska to violate its water sharing agreement. The Supreme Court found in favour of Kansas and required Nebraska to regulate groundwater pumping (Schlager et al. 2012).

Nebraska and its water users struggled to develop an agreed upon process for spanning the chasm between the surface water and groundwater management systems. Over the course of a decade (1994-2004), which witnessed a variety of experiments to settle the intense conflict between surface and groundwater users, the legislature finally adopted a statute that established an integrated water management planning process (Nebraska Department of Natural Resources 2006). The Nebraska Department of Natural Resources (NDNR) was granted the authority to 
declare river basins fully allocated or over allocated. Once such a designation occurred, the NDNR and the affected natural resources districts were required to collaborate to develop integrated management plans. The Platte and the Republican Rivers natural resources districts were the first to develop such plans (Nebraska Department of Natural Resources 2006).

Integrated Management Plans form the foundation for conjunctive water management in Nebraska. Well moratoria and strict pumping limits reduce the pressure on surface water flows. In addition, several districts in the Platte River Basin are experimenting with groundwater recharge projects by placing water in unlined canals and pits to percolate underground (Bradley 2011). While conflicts continue to simmer among the state's groundwater and surface water users and between water users and state agencies, the era of integrated or conjunctive management has arrived in Nebraska.

The form and function of conjunctive water management varies across the states as do the processes and outcomes of such management. The states differ on how broadly based collective action occurs, or to put it another way, the interests and values that are represented in decision-making processes. In Colorado, broad-based participation is built into the water administration system. Individuals, organizations, and state agencies who hold water rights or who regulate water rights have a seat at the table and that table is typically the water court. Any water rights holder who believes his or her water right will be affected by a decision may participate in court processes. Given such a process, the State Water Engineer, as a routine matter, convenes advisory groups consisting of water rights holders to guide the development of regulations before they are brought before a water court for approval. In Nebraska, participation occurs in a more ad hoc fashion. When substantive legislation is required to address water issues, the legislature often convenes commissions and task forces with representatives of different types of water uses from across the state to hold hearings, conduct investigations, and make proposals. In developing integrated management plans, temporary advisory committees may be established to participate in their development. The Arizona water administrative system allows for much more limited participation in conjunctive management processes. Participation involves organizations and agencies with access to Central Arizona Project water and with the financial wherewithal to engage in larger scale conjunctive management projects. A number of interests and uses have been excluded from pursuing different forms of conjunctive management, most notably those that are organised around perennial rivers outside of active management areas. Since state law does not recognise the hydrologic connection between ground and surface water, nor does it provide local jurisdictions with any policy tools to regulate groundwater, rivers are slowly being desiccated with little that surface water rights holders, recreationists, and environmentalists can do (Glennon 2002).

Conjunctive management represents a key form of adaptation to changing biophysical and societal demands among the three states. For Arizona, conjunctive management represented a response to a societal crisis, but later morphed into a response to changing biophysical demands. When the primary beneficiaries - 
groundwater irrigators - of a major surface water project were financially incapable of utilizing the project leaving the state in debt and with surplus water, conjunctive management was adopted. Now conjunctive management is viewed as a key tool in buffering water users against the effects of climate change.

For Colorado and Nebraska, conjunctive management was an important response to biophysical issues that generated conflict. The hydrologic connection between surface water and groundwater had to be actively managed in order to protect surface water flows and the users dependent on those flows. In addition, conjunctive management allows Colorado and Nebraska water users to make tradeoffs between flexibility and security of water rights in order to make better use of existing water supplies. For Colorado, augmentation plans provided flexibility allowing for groundwater use to occur, while also protecting surface water rights. Integrated management plans play a similar role in Nebraska - securing surface water rights and flows while allowing for continued use of groundwater. In turn, integrated management plans set the stage for the development of different forms of conjunctive management.

All three states - Arizona, Colorado, and Nebraska - have witnessed success with conjunctive management. Conjunctive management has allowed water users and the states to address various water related crises and makes possible more active forms of water management. However, each state's conjunctive water management programs also exhibit some limitations. First, environmental issues receive little attention. True, Nebraska is using conjunctive management to recover endangered species on the Platte River, however, that is the price the state must pay in order to protect existing water uses and allow for new water uses in the future. Coordinating the use of hydrologically connected ground and surface water would also allow Arizona to protect relatively rare riparian habitat and the rights of surface water users, but, thus far, the legislature has not been convinced to act. Second, the states have just begun to tap the potential of conjunctive management. The states could more actively coordinate groundwater and surface water use by allowing surface water users to move to groundwater during droughts, with water remaining in streams and rivers to provide for habitat and species protection and for downstream water uses, while limiting pumping and actively storing water underground during wet years. However, such flexibility would come at the potential cost of security of water rights as pumps may not be shut off during wet years.

\subsection{Discussion and Conclusion}

This chapter has shed light on specific instances of conjunctive management and collective action in Australia, Spain and the United States. The nature of these approaches varied, including examples of integrated basin and catchment planning in Australia, Nebraska and Upper Guadalquivir basin; large scale water infrastructure projects involving storage and desalination in Arizona and Almeria; as well as augmentation plans and other agreements in Colorado, Jucar and Catalonia. 
Each had considerable success. Australia's 'top down' water reforms involving national frameworks and state implementation gave rise to a suite of legislation and policy instruments and plans that recognise the importance of managing connected water systems as a single resource. In the United States, the more limited national role produced significant variation among states in their conjunctive management approach, but all three demonstrated success, not least facilitating water users and the states to address various water related crises through more active forms of water management. Finally, in Spain's hybrid and multilevel system, involving regulation, voluntary agreements and informal water markets/trading, conjunctive management is tackling various complex problems across a range of water resources. This approach encompasses the ability to engage with water users groups to create a shared vision and accommodate groundwater recharging through formal agreements. It also has facilitated links between administrative agencies to establish consistent conjunctive management approaches.

However, in their own ways, the experiences in each country also evidenced a number of limitations and challenges. In Australia, despite clear national objectives, the implementation of conjunctive water management via collaborative planning has been patchy. Groundwater and surface water remain siloed, science on connectivity was limited and key water user stakeholders were marginalised from integrated decision-making (Lamontagne et al. 2012, p. i). In terms of collective action, consultation was often inadequate, with a lack of meaningful dialogue, poor information and an absence of time and skill on the part of water users. Smaller users, in particular, felt disenfranchised from the process. In the United States, conjunctive management policy also lagged in some areas, including limited attention being given by the legislature and others to environmental issues, and an absence of more active coordination of groundwater and surface water use. In Arizona, in particular, collective action through the participation of water users in the management process was absent, and in Colorado, such participation was largely limited to the legal and regulatory development phase, as opposed to ongoing management. Although more advanced in pursuing collective action than Australian and the United States, Spain, too, has confronted conjunctive management challenges. There are lingering tensions between groundwater and surface water users, and between upstream and downstream users, both of which may be exacerbated in drought conditions. Further, the political voice of water user groups, and their subsequent participation in decision-making, has been less than ideal.

What broader comparative lessons can be gleaned from these case studies? While there are inherent dangers in generalizing from this type of research, nevertheless, a number of insights can be drawn from our findings across the different contexts and institutional arrangements of the three countries. They suggest some key lessons with regard to the types of settings that facilitate conjunctive management and collective action, and also associated challenges and limitations.

In terms of encouraging a participatory approach to conjunctive management, the case study findings support the proposition that governments and water users are more likely to pursue conjunctive management where social and environmental 
crisis arise. Such crises included over-allocation in Australia, fights spurned by endangered species (Platte River Basin in Nebraska), conflicts between water users in the United States (e.g. Colorado) and Spain (e.g. Jucar and Guadalquivir), battles over how to develop and use allocations (e.g. Arizona and Almeria) and a mix of pressing water problems including marine intrusion, water quality and low surface water availability (Catalonia). Certainly, the ultimate shape of the conjunctive water management responses may vary according to the nature of the crisis (as well as other institutional variables), however, collectively, the findings suggest that its presence is a powerful motivator for parties to engage in conjunctive management.

The case studies reveal a second condition that encourages and enables conjunctive management through collective action, that is, institutional recognition of hydrological connections (between ground and surface water), including, in particular, the devolution of management tools to water users on the ground. The importance of this condition was notable by the impact of its absence in the NSW case study from Australia, as well as limiting access to conjunctive management in Arizona in the United States. In NSW, the policy framework promoted a vision of connectivity and integrated management of surface water and groundwater, however this vision was not translated effectively into state government action and rules. Groundwater and surface water remained isolated with little provision in WSP for integrated management. This effectively stymied local water users in their desire for conjunctive management. Similarly, in Arizona, the failure of state law to recognise the hydrologic connection between ground and surface water effectively excluded different forms of conjunctive management in local jurisdictions outside of active management areas.

The importance of institutional recognition in facilitating conjunctive management was evident across other case studies, as well. There were examples of legal frameworks accommodating conjunctive management, be it through rights of participation in courts and legal recognition of augmentation plans and integrated management plans (United States), or policies that integrate resource management through conjunctive rules, a willingness of government agencies to work with water users groups and agreements tailored to different exchanges between water uses (Spain).

Beyond these pre-conditions, there are lessons about the challenges confronting the ongoing management of conjunctive use. While conjunctive management has the capacity to adapt to changing biophysical circumstances and societal demands, this was not always assured in the case studies. For example, it is apparent that conjunctive management struggles to accommodate a comprehensive suite of environmental issues - this is an issue that legislatures and government agencies need to progress further. This remains an issue in the Unites States, in particular in Arizona, where there has been little progress coordinating the use of hydrologically connected groundwater and surface water to advance the protection of rare riparian habitat. Similarly, in Australia and Spain, much work remains to be done to effectively manage the impacts on groundwater dependent ecosystems and establish environmental water requirements. Entrenching consideration of 
environmental issues within conjunctive programs is accordingly an area that demands policy attention.

Another obstacle to effective conjunctive management was a lack of meaningful engagement of water users in integrated water decision-making and implementation. In NSW, Australia, opportunities to incorporate local water users' knowledge, preferences and ideas relating to conjunctive management and connectivity were stymied by limited consultation, the provision of overly complex data and an inability of government and users to reach agreement. This contrast with Catalonia, Spain, where the political voice and representation of users was better able to contribute a common vision in support of conjunctive management. Meanwhile, the complete exclusion of surface water rights holders, recreationists and environmentalists from the regulation of groundwater outside of active management areas in Arizona, the United States, has undermined broader conjunctive management processes.

Overcoming this obstacle will require institutional settings that better facilitate water users participation in conjunctive management decision-making. While much will depend on context, a range of successful examples from the case studies include commission/taskforces/advisory committees in Nebraska, open court processes to those who hold water rights in Colorado, the use of modelling programmes to generate better comprehension by users of the range of alternatives and harnessing well-organised groundwater user groups to act as interlocutors with the government decision makers in Jucar.

In conclusion, conjunctive management through collective action remains a 'work in progress' across the case studies. While there are some encouraging green shoots appearing in a range of international jurisdictions, notably in terms of policy, legislative and regulatory recognition of groundwater and surface connectivity and integrated management, as is often the case, difficulties arise in effective delivery. Certainly, the presence of a 'crisis' can motive institutional actors, providing of course they have the necessary tools and resources. The greatest challenge is, however, how to effectively engage a broad suite of actors, particularly water users on the ground, to deliver conjunctive management through genuine collective action.

Open Access This chapter is distributed under the terms of the Creative Commons AttributionNoncommercial 2.5 License (http://creativecommons.org/licenses/by-nc/2.5/) which permits any noncommercial use, distribution, and reproduction in any medium, provided the original author(s) and source are credited.

The images or other third party material in this chapter are included in the work's Creative Commons license, unless indicated otherwise in the credit line; if such material is not included in the work's Creative Commons license and the respective action is not permitted by statutory regulation, users will need to obtain permission from the license holder to duplicate, adapt or reproduce the material. 


\section{References}

Aiken D (1999) Balancing endangered species protection and irrigation water rights: the Platte River cooperative agreement. Great Plains Nat Res J 3:119-158

Andreu J, Capilla J, Sanchis E (1996) Generalized decision support system for water resource planning and management including conjunctive water use. Great J Hydrol 177:269-291

Andreu J, Sahuquillo Herráiz A, Solera A, Pulido Velázquez M, Pulido Velázquez D, Paredes Arquiola J (2010) Ejemplo de gestión conjunta de aguas subterráneas y superficiales: la cuenca del Río Mijares. Paper presented at AEUAS, Garantías de la gestión de aguas subterráneas: diagnosis de la situación, Vila-Real, 4 Nov 2010

Arizona Water Banking Authority (2013) Background. http://www.azwaterbank.gov/Background. Accessed 18 June 2013

Baldwin C, Poh-Ling T, White I, Hoverman S, Burry S (2012) How scientific knowledge informs community understanding of groundwater. J Hydrol 474:74-83

Blomquist W, Schlager E, Heikkila T (2004) Common waters, diverging streams: linking institutions and water management in Arizona, California and Colorado. Resources for the Future, Washington, DC

Bradley J (2011) Conjunctive water management. Available via DNR. http://dnr.ne.gov/IWM/ Reports/ConceptualDesignConjunctiveMgmt_032811.pdf. Accessed 18 June 2013

Bricknell S (2010) Environmental crime in Australia. Australian Institute of Criminology, Canberra

Brodie R, Sundaram B, Tottenham R, Hostetler S, Ransley T (2007) An adaptive management framework for connected groundwater-surface water resources in Australia. Bureau of Rural Sciences, Canberra

Colby B, Jacobs K (eds) (2007) Arizona water policy: management innovations in an urbanizing, arid region. Resources for the Future, Washington, DC

Cowan J (2012) Physical and legal influences on groundwater. Available via Water. http://water. state.co.us/DWRDocs/Reports/Presentations/Pages/AtoZPresentations.aspx. Accessed 18 June 2013

Dillon P, Pavelic P, Page D, Beringen H, Ward J (2009) Managed aquifer recharge: an introduction. Waterlines report no 13, National Water Commission, Canberra

Dillon P, Toze S, Page D, Vanderzalm J, Bekele E, Sidhu J, Rinck-Pfeiffer S (2010) Managed aquifer recharge: rediscovering nature as a leading edge technology. Water Sci Technol 62 (10):2338-2345

Evans WR, Evans RS, Holland GF (2012) Conjunctive use and management of groundwater and surface water within existing irrigation commands: the need for a new focus on an old paradigm. Thematic paper, Global Environment Facility, GEF ID 3726. Available via Groundwater Governance. http://www.groundwatergovernance.org/fileadmin/user_upload/groundwatergovernance/ docs/Thematic_papers/GWG_Thematic_Paper_2_01.pdf. Accessed 10 May 2014

Ferrer J, Garijo L (2013) Mercados del agua y flexibilización del marco concesional (Confederación Hidrográfica del Júcar). Paper presented at XI Seminario Nacional Transparencia y concesiones, Observatorio del Agua de la Fundación Botín, 17 Jan 2013

Flores Montoya F (1998) Ventajas del aprovechamiento conjunto de aguas superficiales y subterráneas: el ejemplo de Madrid. In: Fernández Rubio R, Sánchez Fernández JA, López Camacho B, López Geta JA (eds) Aguas subterráneas y abastecimiento urbano. ITGE, Madrid

Freeman D (2010) Implementing the Endangered Species Act on the Platte Basin water commons. University Press of Colorado, Boulder

Gardner A, Bartlett R, Gray J (2009) Water resources law. LexisNexis, Chatswood

Garduño H, Foster S, Nanni M, Kemper K, Tuinhof A, Koundouri P (2010) Sustainable groundwater management: concepts and tools, GW-MATE Briefing note series; World Bank gestión sustentable del agua subterránea. Conceptos y herramientas; Serie de notas informativas Nota 10. World Bank, Washington, DC.

Getches D (2008) Water law in a nutshell, 4th edn. West Publishing, St Paul 
Glennon R (1995) Coattails of the past: using and financing the central Arizona project. Arizona State Law Rev 2(2):667-756

Glennon R (2002) Water follies. Island Press, Washington, DC

Godden L, Foerster A (2011) Introduction: institutional transitions and water law governance. J Water Law 22:53-57

Gray J (2010) Water trading and regulation in Australia. In: Saddy A, Linares Martínez A (eds) Dereito das infraestructuras: Um estudo dos distintos mercados regulados. Lumen Juris, Rio de Janerio, pp 753-792

Gray J (2012) The legal framework for water trading in the Murray-Darling Basin: an overwhelming success? Environ Plan Law J 29:328-349

Harnsbarger R (1984) Nebraska water law and administration. Butterworth Legal Publishers, Austin

Holley C, Sinclair D (2011) Collaborative governance and adaptive management: (mis) applications to groundwater, salinity and run-off. Aust J Nat Resour Law Policy 14(1):37-69

Holley C, Sinclair D (2012) Compliance and enforcement of water licences in NSW: limitations in law, policy and institutions. Aust J Nat Resour Law Policy 15(2):149-189

Holley C, Sinclair D (2013a) Non-urban water metering policy: water users' views on metering and metering upgrades in NSW. Aust J Nat Resour Law Policy 16(2):101-131

Holley C, Sinclair D (2013b) Deliberative participation, environmental law and collaborative governance: insights from surface and groundwater studies. Environ Plan Law J 30(1):32-55

Holley C, Gunningham N, Shearing C (2011) The new environmental governance. Earthscan, Abingdon

Howe C (2002) Policy issues and institutional impediments in the management of groundwater: lessons from case studies. Environ Dev Econ 7:625-641

Between the Commonwealth of Australia and the Governments of New South Wales, Victoria, Queensland, South Australia, the Australian Capital Territory and the Northern Territory (2004) Intergovernmental Agreement on a National Water Initiative (IANWI). Canberra

Kelly B, Merrick N, Dent B, Milne-Home W, Yates D (2007) Groundwater knowledge and gaps in the Namoi catchment management area. National Centre for Groundwater Management, University of Technology, Sydney

Kenny J (2011) Platte river recovery implementation program: four years into the first increment. Available via Prairie Fire. http://www.prairiefirenewspaper.com/2011/04/platte-river-recoveryimplementation-program-four-years-into-the-first-increment. Accessed 18 June 2013

Lamontagne S, Graham D, Household I, Middlemis H, Ross A (2012) Groundwater-surface water interactions: implications for water resources management. Workshop summary report, National Water Commission, Canberra

Leshy J, Belanger J (1988) Arizona law: where ground and surface water meet. Arizona State Law J 20(3):657-748

Llamas MR, Martinez-Santos P, de la Hera A (2007) Dimensions of sustainability in regard to groundwater resources development: an overview. In: Ragone S, de la Hera A, HernandezMora N, Bergkamp G, McKay J (eds) Global importance of groundwater in the 21st century: the international symposium in groundwater sustainability, Alicante, 24-27 Jan 2006. National Groundwater Association Press, Westerville

Lopez-Gunn E, Llamas MR, Garrido A, Sanz D (2011) Groundwater management. In: Rogers P (ed) Treatise in water science, vol 1. Elsevier, Amsterdam/Hackensack, pp 97-127

López-Gunn E, Rica M, van Cauwenbergh N (2012) Taming the groundwater chaos. In: De Stefano L, Llamas M (eds) Water, agriculture and the environment: can we square the circle? Taylor and Francis, Leiden, pp 227-240, Available at: http://www.fundacionbotin.org/file/ 44920/. Accessed 10 May 2014

Millar I (2005) Testing the waters: legal challenges to water sharing plans in NSW. In: Water Law in Western Australia, conference, July 2005. Available via EDOWA. http://www.edowa.org. au/files/presentations/wliwa.Millar.Testing.pdf. Accessed 10 May 2014

National Water Commission (NWC) (2008) Groundwater position statement. NWC, Canberra

National Water Commission (NWC) (2011a) National water planning report card 2011. Australian Government, Canberra 
National Water Commission (NWC) (2011b) The NWI-securing Australia's water future 2011 assessment. Australian Government, Canberra

Natural Resources Commission (NRC) (2013) Water sharing plan reviews. Available via NRC. http://nrc.nsw.gov.au/Workwedo/WaterSharingPlanReviews.aspx. Accessed 10 May 2014

Nebraska Department of Natural Resources (2006) Integrated water management planning process. Brochure, Lincoln

New South Wales (NSW) Office of Water (2013) Water sharing plans under review. Available via NSW Office of Water. http://www.water.nsw.gov.au/Water-management/Water-sharingplans/Plans-under-review/plans-remade. Accessed 10 May 2014

New South Wales Government (NSWG) (2011) Achieving sustainable groundwater entitlements. Available via Office of Water. http://www.water.nsw.gov.au/Water-management/Water-sharingplans/Plans-commenced/achieving-sustainable-groundwater-entitlements-program. Accessed 26 Nov 2013

O'Rourke M, Bailey A (2010) Peel valley water sharing plan, an integrated approach. In: National Groundwater conference, Canberra, 31 Oct-4 Nov 2010

Parsons S, Evans R, Hoban M (2008) Surface-groundwater connectivity assessment. A report to the Australian government from the CSIRO Murray-Darling Basin sustainable yields project. CSIRO, Canberra

Petheram C, Bristow K, Nelson P (2008) Understanding and managing groundwater and salinity in a tropical conjunctive water use irrigation district. Agric Water Manag 9(5):1167-1179

Planas JM (2010) Participación de los usuarios de aguas subterráneas en la gestión y planificación de los recursos hídricos. Paper presented at the symposium on user participation in groundwater management and water resources planning, Valladolid, 27 Jan 2010

Reisner M (1993) Cadillac desert, revised edn. Penguin Books, New York

Rica M, Dumont A, Villarroya F, Lopez-Gunn E, Rica M, Dumont A, Villarroya F, Lopez-Gunn E (2014) Whither collective action? Upscaling collective actions, politics and basin management in the process of 'legitimising' an informal groundwater economy. Water Int 39(4):520-533

Ross A (2012a) Easy to say, hard to do: integrated surface water and groundwater management in the Murray-Darling Basin. Water Policy 14:709-724

Ross A (2012b) Water connecting people adapting. PhD dissertation, Australian National University

Sahuquillo A (2009) La importancia de las aguas subterráneas (coste/uso intensivo/ almacenamiento subterráneo/uso conjunto/protección acuíferos). X Programa de Promoción de la Cultura Científica y Tecnológica. Rev R Acad Cienc Exact Fís Nat (Esp) 103(1):97-114

Schlager E, Blomquist W (2008) Embracing watershed politics. University Press of Colorado, Boulder

Schlager E, Heikkila T, Case C (2012) The costs of compliance with interstate agreements: lessons from water compacts in the western United States. Publius J Federalism. doi:10.1093/publius/ pjs017

Schlumberger Water Services (SWS) (2012) Namoi catchment water study independent expert interim final report. DTIRIS NSW, Orange

SKM (2011) National framework for integrated management of connected groundwater and surface water systems. Waterlines report 57. National Water Commission, Canberra

Tan PL, Bowmer K, Baldwin C (2012) Continued challenges in the policy and legal framework for collaborative water planning. J Hydrol 474:84-91 